\title{
Effects of some factors on carotenoid biosynthesis by Rhodotorula Muclaginosa
}

\author{
Ly Thi Minh Hien ${ }^{1 *}$, Pham Thi Hang Nga ${ }^{1}$ \\ ${ }^{1}$ Ho Chi Minh City Open University, Vietnam \\ *Corresponding author: hien.ltminh@ou.edu.vn
}

\begin{tabular}{|c|c|}
\hline ARTICLE INFO & ABSTRACT \\
\hline $\begin{array}{l}\text { DOI:10.46223/HCMCOUJS. } \\
\text { tech.en.9.1.352.2019 }\end{array}$ & $\begin{array}{l}\text { Carotenoid compounds are popular natural antioxidants that } \\
\text { are often isolated from plants. There have been more and more } \\
\text { researches on carotenoid biosynthesis towards lowering product } \\
\text { prices. In this study, in order to produce carotenoid, Rhodotorula }\end{array}$ \\
\hline Received: March 1 ${ }^{\text {st }}, 2019$ & $\begin{array}{l}\text { mucilaginosa was grown on aqueous media composed of car } \\
\text { source (glucose, glycerol), nitrogen source (yeast ext }\end{array}$ \\
\hline Revised: March 10 ${ }^{\text {th }}, 2019$ & $\left.\left(\mathrm{NH}_{4}\right)_{2} \mathrm{SO}_{4}\right)$. The optimum nutrient concentration was $10 \mathrm{~g} / \mathrm{L}$ \\
\hline Accepted: May 21 ${ }^{\text {st }}, 2019$ & $\begin{array}{l}\text { glucose, } 10 \mathrm{~g} / \mathrm{L} \text { glycerol, the ratio of yeast extract and }\left(\mathrm{NH}_{4}\right)_{2} \mathrm{SO}_{4} \\
(3: 7) \text {. The fermentation time for obtaining the highest carotenoid } \\
\text { yield was } 10 \text { days in our research condition. Additionally, some }\end{array}$ \\
\hline Keywords: & oxidative stress environment for Rhodotorula mucilaginosa was \\
\hline $\begin{array}{l}\text { arotenoid, biosynthesis, } \\
\text { fermentation, Rhodotorula } \\
\text { Mucilaginosa }\end{array}$ & $\begin{array}{l}\text { being studied. The result has shown that the low level of } \mathrm{Cu}^{2+} \\
(4.5 \mathrm{mM}) \text { or } 1 \% \mathrm{H}_{2} \mathrm{O}_{2} \text { solution }(\% \mathrm{v} / \mathrm{v}) \text { in the fermentation media }\end{array}$ \\
\hline
\end{tabular}

\section{Introduction}

Carotenoid compounds are tetraterpenoid, consisting of highly unsaturated isoprene derivatives. These compounds are the class of natural pigments, displaying yellow, orange or red color in plants. In addition to popular use as food colorants, carotenoids were also famous for their pro-vitamin and antioxidant activity.

Not only plants but also microorganisms can synthesize carotenoids to protect their cell from radicals. More and more researches on single-cell carotenoid have been done in recent years. Red yeast Rhodotorula is one of the most popular genera used to produce carotenoids. Most of the researches' purpose was to find out the optimum mediums for carotenoid biosynthesis, especially nutrient concentration.

In order to evaluate the effect of supplementation, Bonadio, Freita, and Mutton (2018) incubated yeast Rhodotorula rubra L02 in mediums with different concentrations of nitrogen, phosphorus, zinc and magnesium. The dry biomass and carotenoid yield were $2 \mathrm{~g} / \mathrm{L}$ and $0.003 \mathrm{mg} / \mathrm{L}$, respectively. In another report, the carbon and nitrogen ratio was changed in the fermentation medium and the result showed that the increase of $\mathrm{C} / \mathrm{N}$ ratio from 70 to 120 led to an increased carotenoid synthesis. 
Naghavi, Hanachi, Soudi, Saboora, and Ghorbani (2013) utilized Rhodotorula slooffiae and Rhodotorula mucilaginosa isolated from leather tanning wastewater as a culture to produce carotenoid in the synthetic medium including glucose, yeast extract, $\mathrm{NH}_{4}\left(\mathrm{SO}_{4}\right)_{2}, \ldots$ The strain of Rhodotorula mucilaginosa had more potential for carotenoid biosynthesis.

Apart from the synthetic fermentation medium, some affordable complex mediums like inexpensive agricultural products or byproducts were utilized for yeast growth. Petrika, Benesováa, and Márová (2014) tested the carotenoid production by four red yeast strains with the spent coffee ground as substrate. In 2018, Besarab, Gerasimovich, Kanterova, and Novikused beer wort as the substrate to biosynthesize carotenoids by some Rhodotorula strains. The highest carotenoid yields (over $80 \mu \mathrm{g} / \mathrm{g}$ dry biomass) were recorded for the strain Rhodotorula glutinis BIM Y-158 and BIM Y-253.

The aim of this study was to evaluate the impact of nutrients (carbon sources, nitrogen sources), oxidant stress factors $\left(\mathrm{CuSO}_{4}, \mathrm{H}_{2} \mathrm{O}_{2}\right)$ and fermentation time on the biomass and carotenoid yield.

\section{Materials and methods}

\subsection{Microorganism}

Rhodotorula mucilaginosa was purchased from the Institute of Microorganism and Biotechnology, Vietnam National University, Ha Noi and maintained for further use on YDP agar $\left(20 \mathrm{~g} / \mathrm{L}\right.$ of peptone, $10 \mathrm{~g} / \mathrm{L}$ of yeast extract, $20 \mathrm{~g} / \mathrm{L}$ of glucose and $20 \mathrm{~g} / \mathrm{L}$ of agar) at $4{ }^{\circ} \mathrm{C}$.

YDP liquid medium was used to prepare the inoculum. Cultivation was carried out in $250 \mathrm{~mL}$ Erlenmeyer containing $100 \mathrm{~mL}$ of the medium at $30^{\circ} \mathrm{C}$ for $24 \mathrm{~h}$ with shaking at $200 \mathrm{rpm}$. Then the yeast cells were seeded at a density of $10^{6}$ cells $/ \mathrm{mL}$ in a $150 \mathrm{~mL}$ experimental medium.

\subsection{Experiments}

Firstly, nutrient concentration was changed in 1L medium: the ratios of glycerol and glucose $(10: 10,7: 13,5: 15,4: 16 \mathrm{~g} / \mathrm{g})$ and the ratios of organic nitrogen (from yeast extract) and inorganic nitrogen (from $\left.\mathrm{NH}_{4}\left(\mathrm{SO}_{4}\right)_{2}\right)$ (10:0, 9:1, 7:3, 5:5, 3:7).

Secondly, the fermentation time was evaluated. The red yeast was grown and two parameters (dry biomass yield and carotenoid concentration) were determined each day so as to identify the best time for cell harvest.

Last, some oxidant stress factors were put into the cultivation medium to evaluate the effectiveness of them on carotenoid biosynthesis. These factors were: $\mathrm{CuSO}_{4}$ concentration $(0.0 ; 0.5 ; 2.5 ; 4.5 ; 6.5 \mathrm{mM})$ and the volume of $1 \% \mathrm{H}_{2} \mathrm{O}_{2}$ solution in $100 \mathrm{~mL}$ culture $(0.0,1.0 ; 2.5$ and $5.0 \mathrm{~mL})$.

\subsection{Dry biomass yield determination}

After incubation, the specified volume of culture was centrifuged for $15 \mathrm{~min}$ at $3000 \mathrm{rpm}$ and rinsed with distilled water. The wet-cell biomass was dried at $80^{\circ} \mathrm{C}$ to the constant weight. The dry biomass yield unit has been $\mathrm{g} / \mathrm{L}$. 


\subsection{Carotenoid extraction and determination}

The wet-cell biomass was also ground with glass powder $(1: 1 \mathrm{w} / \mathrm{w})$ within $20 \mathrm{~min}$ to break the yeast wall. Subsequently, $15 \mathrm{~mL}$ acetone was added to extract carotenoid from the ground cell. The extraction was implemented again with the same acetone volume. The total acetone extraction was used to quantitatively determine carotenoid biosynthesis by spectrophotometer at $454 \mathrm{~nm}$.

\subsection{Statistical analysis}

The data analysis of dry biomass yield $(\mathrm{g} / \mathrm{L})$ and carotenoid yield $(\mu \mathrm{g} / \mathrm{L})$ from the experiments was carried out by Statgraphic plus 3.0 software with the ANOVA method.

\section{Results and discussion}

\subsection{Effect of the ratio glycerol and glucose on biosynthesis}

Glucose is often made use of as a carbon source for yeast in inoculum and fermentation medium. In many reports on carotenoid biosynthesis, glycerol as substrate was supplemented to the fermentation medium (Cutzu et al., 2013; Kot, Błażejak, Kurcz, Gientka, \& Kieliszek, 2016; Kot et al., 2017).

In this experiment, the various ratios of glycerol and glucose led to a significant difference in the carotenoid yield but did not change the dry biomass yield. The utilization of glycerol or glucose as the only carbon source indicated the lowest carotenoid yield. The medium contained both carbon sources with the same quantity of $10 \mathrm{~g} / \mathrm{L}$ was the optimum parameter and produced the highest carotenoid yield: $4703.9 \mu \mathrm{g} / \mathrm{L}$ (Table 1).

Many different carotenoid yields were indicated in different reports which utilized Rhodotorula mucilaginosa yeast. Cheng and Yang (2016) incubated R. mucilaginosa to produce carotenoid with some food waste and YM medium (consisting of glucose, peptone, yeast extract and malt extract) as the control medium. The carotenoid yields were obtained from 1107.4 to $2337.5 \mu \mathrm{g} / \mathrm{L}$. In another journal, Manimala and Murugesan (2017) evaluated the carotenoid production using cheap complex substrates (rice bran, wheat bran, coconut oil cake, sesame oil cake, ...). The carotenoid yield was ranging from $12.0-12.5 \mathrm{mg} / \mathrm{L}$.

\section{Table 1}

Dry biomass and carotenoid yield in mediums with different glycerol/glucose ratio

\section{Glycerol/glucose ratio}

$(\mathrm{g} / \mathrm{g}$ in $1 \mathrm{~L})$
Carotenoid yield

$(\mu \mathrm{g} / \mathrm{L})$
Dry biomass yield

$(\mathrm{g} / \mathrm{L})$

\begin{tabular}{ccc}
\hline $20: 0$ & $1977.2^{\mathrm{c}}$ & 4.006 \\
\hline $\mathbf{1 0 : 1 0}$ & $\mathbf{4 7 0 3 . 9}^{\mathrm{a}}$ & $\mathbf{4 . 1 6 0}$ \\
\hline $7: 13$ & $2797.2^{\mathrm{b}}$ & 4.407
\end{tabular}




\section{Glycerol/glucose ratio}

$(\mathrm{g} / \mathrm{g}$ in $1 \mathrm{~L})$

\section{Carotenoid yield}

$(\mu \mathrm{g} / \mathbf{L})$
Dry biomass yield

$(\mathrm{g} / \mathrm{L})$

\begin{tabular}{ccc}
\hline $5: 15$ & $2797.2^{\mathrm{b}}$ & 4.407 \\
\hline $3: 17$ & $3733.3^{\mathrm{ab}}$ & 4.213 \\
\hline $0: 20$ & $1972.3^{\mathrm{c}}$ & 3.823
\end{tabular}

Note: The different letters $(a, b, c)$ in the same column showed the significant difference of the dry biomass weight and carotenoid yield. The (ns) showed that the data in the column were not statistically different

Source: The researcher's data analysis

\subsection{Effect of the ratio yeast extract and ammonium sulfate on biosynthesis}

Yeast extract and ammonium sulfate can supply nitrogen for the yeast growth in many types of research. The ratio of yeast extract and ammonium sulfate did not make an effect on carotenoid yield. However, the presence of yeast extract raised the dry biomass yield of Rhodotorula yeast (Table 2). To get the high yield of the product and decrease the process cost, the ratio of yeast extract and ammonium sulfate was chosen for further research was (3:7).

\section{Table 2}

Dry biomass and carotenoid yield in mediums with different yeast extract/ammonium sulfate ratio

\section{Yeast extract/ammonium} sulfate ratio

$(\mathrm{g} / \mathrm{g}$ in $1 \mathrm{~L})$
Carotenoid yield

$(\mu \mathrm{g} / \mathrm{L})$
Dry biomass yield

$(\mathrm{g} / \mathrm{L})$

\begin{tabular}{ccc}
\hline $10: 0$ & 1040.10 & $6.427^{\mathrm{a}}$ \\
\hline $9: 1$ & 540.87 & $4.934^{\mathrm{ab}}$ \\
\hline $7: 3$ & 1340.90 & $5.670^{\mathrm{a}}$ \\
\hline $5: 5$ & 887.63 & $4.832^{\mathrm{ab}}$ \\
\hline $\mathbf{3 : 7}$ & $\mathbf{9 2 7 . 5 0}$ & $\mathbf{4 . 7 9 3}^{\mathrm{ab}}$ \\
\hline $1: 9$ & 568.63 & $3.247^{\mathrm{b}}$ \\
\hline $0: 10$ & 597.20 & $0.477^{\mathrm{c}}$
\end{tabular}

Note: The different letters $(\mathrm{a}, \mathrm{b}, \mathrm{c})$ in the same column showed the significant difference of the dry biomass weight and carotenoid yield

Source: The researcher's data analysis 


\subsection{Effect of the fermentation time on biosynthesis}

The fermentation time is also an important parameter for harvesting the bio-product. In this experiment, the dry biomass and carotenoid yield were identified once per two days through ten-day incubation. Generally, there was an increase in both the yields due to the rise of the incubation time. The highest dry biomass gained on the eighth day at $7.437 \mathrm{~g} / \mathrm{L}$ but after that, the carotenoid yield continues rising until the last day of this experiment. Hence, ten days was the time to harvest the carotenoid of our Rhodotorula mucilaginosa and the carotenoid obtained at $809.59 \mu \mathrm{g} / \mathrm{L}$. Compare with some reports, the carotenoid quantity accumulated from other Rhodotorula mucilaginosa strains quite different. Petrika et al. (2014) and Naghavi et al. (2013) fermented $R$. mucilaginosa and carotenoid production gained at $4.69 \mathrm{mg} / \mathrm{L}$ and $8 \mathrm{mg} / \mathrm{g}$ dry biomass, respectively.

\section{Table 3}

Dry biomass and carotenoid yield in ten-day fermentation

Fermentation time

(day)
Carotenoid yield

$(\mu \mathrm{g} / \mathrm{L})$
Dry biomass yield

$(\mathrm{g} / \mathrm{L})$

\begin{tabular}{ccc}
\hline 2 & $248.77^{\mathrm{c}}$ & $3.520^{\mathrm{c}}$ \\
\hline 4 & $540.88^{\mathrm{b}}$ & $5.749^{\mathrm{b}}$ \\
\hline 6 & $618.03^{\mathrm{b}}$ & $6.136^{\mathrm{ab}}$ \\
\hline 8 & $579.02^{\mathrm{b}}$ & $7.437^{\mathrm{a}}$ \\
\hline $\mathbf{1 0}$ & $\mathbf{8 0 9 . 5 9 ^ { \mathrm { a } }}$ & $\mathbf{7 . 2 0 0 ^ { \mathrm { a } }}$
\end{tabular}

Note: The different letters $(a, b, c)$ in the same column showed the significant difference of the dry biomass weight and carotenoid yield

Source: The researcher's data analysis

\subsection{Effect of the oxidant stress factors on biosynthesis}

Carotenoids are the secondary metabolic products that protect the yeast cell from oxidant factors. Marova et al. (2012) used some stress factors (high concentration of $\mathrm{NaCl}$ and peroxide) to test the carotenoid accumulation of some yeast strains.

Exposure to $\mathrm{H}_{2} \mathrm{O}_{2}$ or $\mathrm{Cu}(\mathrm{II})$ cation would modify the carotenoid content in $R$. mucilaginosa RCL-11, both qualitatively and quantitatively (Irazustaa, Nieto-Penalvera, Cabrala, Amoroso, \& de Figueroa, 2013). Hence, in our research, the solution of $\mathrm{H}_{2} \mathrm{O}_{2} / \mathrm{CuSO}_{4}$ was supplemented to the medium to create an oxidant stress condition in cell growth.

The addition of $\mathrm{H}_{2} \mathrm{O}_{2}$ solution made the effect on the carotenoid synthesis clearer than the yeast biomass. Without $\mathrm{H}_{2} \mathrm{O}_{2}$, the carotenoid yield was significantly lower but too much $\mathrm{H}_{2} \mathrm{O}_{2}$ concentration (from $5 \%$ solution of $\mathrm{H}_{2} \mathrm{O}_{2}$ ) could inhibit the yeast growth and carotenoid biosynthesis. The $\mathrm{H}_{2} \mathrm{O}_{2}$ solution percentage of $1.0 \%$ and $2.5 \%$ obtained a significantly higher carotenoid yield (1379.1 and $1380.3 \mu \mathrm{g} / \mathrm{L}$, respectively) (Table 4 ). 


\section{Table 4}

Dry biomass and carotenoid yield in mediums with different volume of $1 \% \mathrm{H}_{2} \mathrm{O}_{2}$ solution

\begin{tabular}{ccc}
$\begin{array}{c}\text { The percentage of } 1 \% \mathrm{H}_{2} \mathrm{O}_{2} \\
\text { solution } \\
(\% \text { v/v) }\end{array}$ & $\begin{array}{c}\text { Carotenoid yield } \\
(\boldsymbol{\mu g} / \mathbf{L})\end{array}$ & $\begin{array}{c}\text { Dry biomass yield } \\
(\mathbf{g} / \mathbf{L})\end{array}$ \\
\hline 0.0 & $442.07^{\mathrm{b}}$ & $5.626^{\mathrm{ab}}$ \\
\hline 1.0 & $1379.1^{\mathrm{a}}$ & $6.845^{\mathrm{a}}$ \\
\hline 2.5 & $1380.3^{\mathrm{a}}$ & $6.288^{\mathrm{a}}$ \\
\hline 5.0 & $310.31^{\mathrm{b}}$ & $4.477^{\mathrm{b}}$
\end{tabular}

Note: The different letters $(a, b, c)$ in the same column showed the significant difference of the dry biomass weight and carotenoid yield

Source: The researcher's data analysis

The concentration of $\mathrm{CuSO}_{4}$ also made the various carotenoid yields after fermentation. The best biosynthesis was identified with $4.5 \mathrm{mM} \mathrm{CuSO}_{4}$ in the medium and gained the carotenoid yield of $1855.0 \mu \mathrm{g} / \mathrm{L}$. The lower than $4.5 \mathrm{mM}$ of $\mathrm{CuSO}_{4}$ concentration was decreased the yield but the increase of this parameter to $6.5 \mathrm{mM}$ led to the death of the yeast because of stress (Table 5).

\section{Table 5}

Dry biomass and carotenoid yield in mediums with different concentration of $\mathrm{CuSO}_{4}$

\section{Concentration of $\mathrm{CuSO}_{4}$} $(\mathbf{m M})$

\section{Carotenoid yield}

$$
(\mu \mathrm{g} / \mathrm{L})
$$

\begin{tabular}{cc}
\hline 0.0 & $764.58^{\mathrm{b}}$ \\
\hline 0.5 & $573.68^{\mathrm{b}}$ \\
\hline 2.5 & $918.03^{\mathrm{b}}$ \\
\hline 4.5 & $1855.00^{\mathrm{a}}$ \\
\hline 6.5 & $0.00^{\mathrm{a}}$
\end{tabular}

Note: The different letters $(a, b, c)$ in the same column showed the significant difference of carotenoid yield Source: The researcher's data analysis

\section{Conclusion}

In conclusion, the ratios of carbon sources influenced on the carotenoid yield and the ratios of nitrogen sources mainly affected the dry biomass yield in our fermentation conditions. After eight-day incubation, the highest biomass gained, while the carotenoid production continuously rose until the tenth day. Both of the oxidation stress factors $\left(\mathrm{CuSO}_{4}\right.$ and $\left.\mathrm{H}_{2} \mathrm{O}_{2}\right)$ 
could increase the carotenoid accumulation in their limitation. Over the optimum concentration, the oxidant stress inhibited or even stopped the yeast growth.

\section{ACKNOWLEDGEMENT}

I would like to express my great appreciation to the Laboratory of Biochemistry and Laboratory of Food Technology Ho Chi Minh City Open University for supporting us in our project. I would also like to extend my thanks to the Faculty of Biotechnology, Ho Chi Minh City Open University for their help in offering me the resource in running the experiments.

\section{References}

Besarab, N. V., Gerasimovich, K. M., Kanterova, A. V., \& Novik, G. I. (2018). Biosynthetic production of carotenoids using yeast strains of genus Rhodotorula on the cheap beer wort substrate. Journal Microbiology Biotechnology Food Science, 7(4), 383-386.

Bonadio, M. P., Freita, L. A., \& Mutton, M. J. R. (2018). Carotenoid production in sugarcane juice and synthetic media supplemented with nutrients by Rhodotorula rubra 102 . Brazilian Journal of Microbiology, 49(4), 872-878.

Braunwald, T., Schwemmlein, L., Graeff-Hönninger, S., French, W. T., Hernandez, R., Holmes, W. E., \& Claupein, W. (2013). Effect of different C/N ratios on carotenoid and lipid production by Rhodotorula glutinis. Applied Microbiology and Biotechnology, 97(14), 6581-6588.

Cheng, Y. I., \& Yang, C. F. (2016). Using strain Rhodotorula mucilaginosa to produce carotenoids using food wastes. Journal of the Taiwan Institute of Chemical Engineer, 6, 270-275.

Cutzu, R., Coi, A., Rosso, F., Bardi, L., Ciani, M., Budroni, M., ... Mannazzu, I. (2013). From crude glycerol to carotenoids by using a Rhodotorula glutinis mutant. World Journal of Microbiology and Biotechnology, 29(6), 1009-1017.

Irazustaa, V., Nieto-Penalvera, C. G., Cabrala, M. E., Amoroso, M. J., \& de Figueroa, L. I. C. (2013). Relationship among carotenoid production, copper bioremediation and oxidative stress in Rhodotorula mucilaginosa RCL-11. Process Biochemistry, 48(5/6), 803-809.

Kot, A. M., Błażejak, S., Kurcz, A., Bryś, J., Gientka, I., Bzducha-Wróbel, A., ... Reczek, L. (2017). Effect of initial $\mathrm{pH}$ of medium with potato wastewater and glycerol on protein, lipid and carotenoid biosynthesis by Rhodotorula glutinis. Electronic Journal of Biotechnology, 27(c), 25-31.

Kot, A. M., Błażejak, S., Kurcz, A., Gientka, I., \& Kieliszek, M. (2016). Rhodotorula glutinispotential source of lipids, carotenoids, and enzymes for use in industries. Applied Microbiology and Biotechnology, 100, 6103-6117.

Maldonade, I. R., Rodriguez-Amaya, D. B., \& Scamparini, A. R. P. (2012). Statistical optimisation of cell growth and carotenoid production by Rhodotorula mucilaginosa. Brazilian Journal of Microbiology, 43(1), 109-115. 
Manimala, M. R. A., \& Murugesan, R. (2017). Studies on carotenoid pigment production by yeast Rhodotorula mucilaginosa using cheap materials of agro-industrial origin. The Pharma Innovation Journal, 6(1), 80-82.

Marova, I., Carnecka, M., Halienova, A., Certik, M., Dvorakova, T., \& Haronikova, A. (2012). Use of several waste substrates for carotenoid-rich yeast biomass production. Journal of Environmental Management, 95, 338-342.

Naghavi, F. S., Hanachi, P., Soudi, M. R., Saboora, A., \& Ghorbani, A. (2013). Evaluation of the relationship between the incubation time and carotenoid production in Rhodotorula slooffiae and R. mucilaginosa isolated from leather tanning wastewater. Iranian Journal of Basic Medical Sciences, 16(10), 1114-1118.

Petrika, S., Benesováa, P., \& Márová, I. (2014). Bioconversion of spent coffee grounds into carotenoids and othervaluable metabolites by selected red yeast strains. Biochemical Engineering Journal, 90, 307-315.

Yoo, A. Y., Alnaeeli, M., \& Park, J. K. (2016). Production control and characterization of antibacterial carotenoids from the yeast Rhodotorula mucilaginosa AY-01. Process Biochemistry, 51(4), 463-473. 